\title{
A New Gene, bic, with Pleiotropic Effects (with $T P V$ ) for Bicolor Flowers and Dark Olive Brown Seed Coat in Common Bean
}

\author{
Mark J. Bassett ${ }^{1}$ \\ Horticultural Sciences Department, College of Agricultural and Life Sciences, University of Florida, \\ Gainesville, FL 32611 \\ Phillip N. Miklas ${ }^{2}$ \\ United States Department of Agriculture, Agricultural Research Service, Vegetable and Forage Crop \\ Research Unit, Prosser, WA 99350
}

\begin{abstract}
Additional Index words. Phaseolus vulgaris, P. coccineus, interspecific crosses, inheritance
Abstract. 'Painted Lady' (Phaseolus coccineus L.) has bicolor flowers with vermilion banner petal and white wing petals. This flower color pattern is not known in common bean (P. vulgaris $L$.). The bicolor trait was backcrossed into common bean and its inheritance investigated, including allelism tests with other genes in common bean $(T, P$, and $V)$ for flower color or pattern and brown seed coat. A pure line (line 33) with bicolor flower and dark olive brown seed coat was crossed to line 5-593 (no flower pattern and black seed coat). Data from the $F_{2}$ and $F_{3}$ progenies from that cross demonstrated that a single recessive gene controlled both the bicolor flower and dark olive brown seed coat by pleiotropic gene action. Allelism tests between the bicolor trait (line 179c) and standard genetic tester stocks involving the $T, P, V$, and $W b$ (white banner) genes for flower color or seed coat color demonstrated independence of bicolor from those genes and further supported the hypothesis of pleiotropic action on flower and seed coat. Also, the $W b$ gene was demonstrated to be independent of $T$ and $P$. The gene symbol bic is proposed for the bicolor gene.
\end{abstract}

Bassett (2007) wrote a comprehensive review of the genetics of seed-coat color and pattern in common bean (Phaseolus vulgaris). The gene loci $T, P$, and $V$ have multiple alleles, which express pleiotropic effects on color and pattern in flowers and seed coats. The pattern gene $T$ is required to express totally colored seed coats with no effect on flower color, whereas $t$ expresses white flower and is required to express seed coats with partly colored patterns (colored vs. white). The color gene $P$ is required to express pigmented seed coats, whereas $p^{\text {mic }}$ expresses a white micropyle stripe (Fig. 1) on seed coats (Bassett, 1998, 2003a). The $p$ allele expresses white seed coat and flower, and the $p^{\text {hbw }}$ and $p^{\text {stp }}$ alleles express patterned flower color and seed coat color (Bassett, 1996, 2003a).

The color-modifying gene $V$ (with $T P B$ ) is required to express bishops violet flower and black seed coat, whereas $v$ expresses white flower and (with $T P B$ ) mineral brown seed coat. The $v^{\text {lae }}$ allele expresses pale pink flowers, with the banner petal expressing much darker pink than the wing petals. Thus, $v^{\text {lae }}$ is a flower color pattern gene. The $V^{\text {wf }}$ gene was transferred from Phaseolus coccineus to $P$. vulgaris by interspecific crossing and expresses white flowers without any pleiotropic effect on the color of seed coat (Bassett, 1997). Thus, (with $B$ ) $V^{\mathrm{wf}}$ expresses black seed coat. The flower color pattern gene $w b$ (with $V$ ) expresses (nearly) white banner petal and slight loss of violet color in the wing petals (Bassett, 1993). The $w b$ pattern gene was transferred from $P$. coccineus to common bean by interspecific crossing. Although $w b$ was reported (Bassett, 1993 ) to be nonallelic with $V$ and $B l u$, additional test crosses

Received for publication 16 Oct. 2006. Accepted for publication 27 Jan. 2007. ${ }^{1}$ Professor emeritus.

${ }^{2}$ Corresponding author. E-mail: pmiklas@pars.ars.usda.gov. are needed to preclude the possibility that $w b$ is a new allele at either $T$ or $P$.

The $P$. coccineus variety 'Painted Lady' has bicolor flowers with a vermilion banner petal and pure white wings. The inheritance of vermilion flower color is not fully known, but the gene for salmon red flower, $\mathrm{Sal}$, is certainly required, and the scarlet flower color gene, $A m$, is probably required (Bassett, 2003b). Lamprecht (1941) used 'Painted Lady' in his inheritance studies of interspecific crosses with $P$. coccineus, noting that 'Painted Lady' had "two-colored" flowers. He further noted that $P$. coccineus (same as his $P$. multiflorus) had two series of two-colored flowers, "one of them with a darker standard than the wings ('Painted Lady' type), the other being the reverse [the white banner $(w b)$ type]." Subsequently, Lamprecht (1948) reported (no supporting data presented) that the two-colored flowers of $P$. coccineus ('Painted Lady' type) were inherited as a recessive trait, to which he assigned the gene symbol bic for bicolorata. The preliminary hypothesis of our research is that the bicolor flower trait may be controlled by a new allele at $\mathrm{Wb}$. The objectives of this paper are 1) to describe the transfer of the bicolor trait into common bean, 2) to investigate the inheritance of bicolor, 3 ) to test for allelism of bicolor with known genes for flower color or pattern, and 4) to make the allelism test crosses $t \times w b$ and $w b \times p^{\text {mic }}$ to complete the testing for allelism in all possible combinations of the genes $T, P, V$, and $W b$.

\section{Materials and Methods}

In 1985, a program was initiated to develop genetic tester stocks for the colors and patterns of common bean seed coats by backcrossing selected recessive alleles, singly and in combination, into a recurrent parent 5-593. The Florida dry bean 


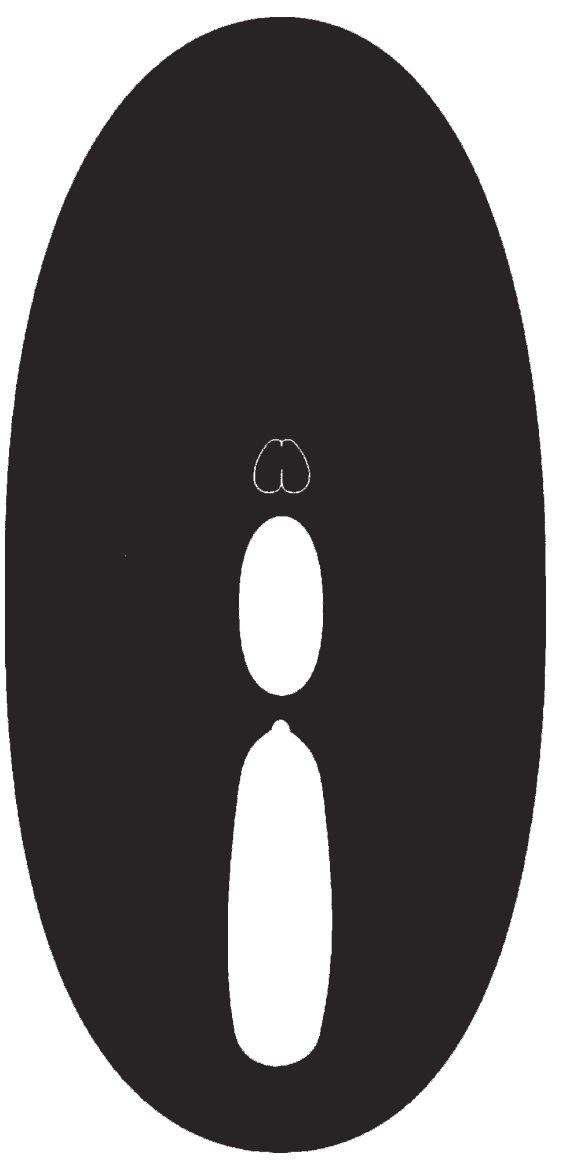

Fig. 1. Ventral view of the common bean seed coat pattern, white micropyle stripe, expressed by $p^{\text {mic }}$

breeding line 5-593 has the seed coat genotype $T P[C r] Z J G B$ $V$ Rk Asp (Bassett, 1994a; Bassett et al., 1999), which expresses shiny ( $J A s p)$, unpatterned black seed coats. Details of the backcross procedure for developing genetic tester stocks were previously described (Bassett, 1994b). In recent years, numerous genetic tester stocks have been developed in the 5-593 genetic background. Upon request, the testers are available for experimental use at the Western Regional Plant Introduction Station at Pullman, Wash.

Seed of 'Painted Lady' was obtained from Seed Savers Exchange, Decorah, Iowa. The fertility of 'Painted Lady' is adversely affected by high temperatures, requiring that crosses with this stock be made in the coldest winter temperature available in Florida. The hybrids of 'Painted Lady' with common bean had low fertility (data not shown). The genetic tester stocks used in this investigation are listed with their Plant Introduction (PI) accession numbers and a phenotypic description in Table 1 . The partly colored pattern, expansa with fibula arcs, is illustrated (Fig. 2).

In Jan. 1999, the cross 'Painted Lady' $\times v \mathrm{BC}_{3} 5-593$ was made. $F_{1}$ progeny were grown in Dec. 1999 and had indeterminate habit and salmon red flower color due to Sal. No bicolor pattern was observed in the flowers, indicating that the bicolor trait is recessive. An $\mathrm{F}_{2}$ progeny of 12 plants were grown in Fall 2000. A single $F_{2}$ plant was selected, having determinate habit and salmon red flowers without bicolor pattern. A cross was made between 5-593 and the $\mathrm{F}_{2}$ plant selection. In Dec. 2000, the $\mathrm{BC}_{1}-\mathrm{F}_{1}$ progeny of the backcross to 5-593 were grown, and
Table 1. Genetic tester stocks in common bean used in this investigation with Plant Introduction (PI) accession numbers and phenotype description.

\begin{tabular}{|c|c|c|c|}
\hline Code & Genetic stock & PI number & $\begin{array}{c}\text { Seed coat and } \\
\text { flower description }\end{array}$ \\
\hline$\overline{\mathrm{P}_{1}}$ & $5-593$ & 608674 & $\begin{array}{l}\text { Black seed, } \\
\text { purple flower }\end{array}$ \\
\hline $\mathrm{P}_{2}$ & $v \mathrm{BC}_{3} 5-593$ & 608679 & $\begin{array}{l}\text { Mineral brown } \\
\text { seed, white flower }\end{array}$ \\
\hline $\mathrm{P}_{3}$ & $V^{\mathrm{wf}} \mathrm{BC}_{3} 5-593$ & 608710 & $\begin{array}{l}\text { Black seed, } \\
\text { white flower }\end{array}$ \\
\hline $\mathrm{P}_{4}$ & $w b \mathrm{BC}_{3} 5-593$ & 635121 & $\begin{array}{c}\text { Black seed, white } \\
\text { banner petal }\end{array}$ \\
\hline $\mathrm{P}_{5}$ & $t Z$ Fib $\mathrm{BC}_{3} 5-593^{\mathrm{z}}$ & 608701 & $\begin{array}{l}\text { Expansa with fibula } \\
\text { arcs seed, } \\
\text { white flower }\end{array}$ \\
\hline $\mathrm{P}_{6}$ & $p^{\text {mic }} \mathrm{BC}_{3} 5-593$ & 608709 & $\begin{array}{l}\text { Black seed with } \\
\text { white micropyle } \\
\text { stripe, purple flower }\end{array}$ \\
\hline
\end{tabular}

$\overline{{ }^{2}}$ This stock expresses the partly colored pattern expansa with fibula arcs, where Fib changes self-colored to expansa and suppresses color in the corona zone.

the $\mathrm{F}_{2}$ progeny were planted in the field at Gainesville, Fla., in Spring 2001. This $F_{2}$ population segregated for bicolor flower pattern and at $\mathrm{Sal}$ and $V$. No data were recorded on the segregation frequencies. A single plant selection was made for bicolor flower pattern and salmon red flower color. The $\mathrm{F}_{3}$ progeny of this selection were planted in Spring 2003. Only eight $F_{3}$ plants set seed, and all expressed bicolor flowers. Segregation was observed at Sal for red flowers (data not shown).

In Winter 2003, selections from eight $\mathrm{F}_{4}$ seed lots were crossed to 5-593 in the greenhouse at Prosser, Wash. (i.e., the $\mathrm{BC}_{2}$ of the bicolor flower trait to 5-593 was made). One of the $\mathrm{F}_{4}$ plants selected was designated line 33 ; it had bicolor flowers (Fig. 3) with purple (bishops violet) banner petals (expressed by sal/sal $V V$ ) and dark olive brown seed coats (genotype unknown). In Summer 2004, the $\mathrm{F}_{2}$ progeny of line $33 \times 5$ 593 was grown at Prosser in the field in plot $179 \mathrm{c}$, which segregated for bicolor flower pattern. Data were recorded on segregation for flower color and pattern and seed coat color. Thirty-five plants from the $\mathrm{F}_{2}$ of line $33 \times 5-593$ were randomly selected for progeny testing in $F_{3}$ in Summer 2005. A selection was made from an $\mathrm{F}_{3}$ progeny that was true breeding for bicolor flower and dark olive brown seed coat, designated hereafter as $179 \mathrm{c}$. The dark olive brown seed coat closely approximates the color of the Royal Horticultural Society Fan 4, Brown Group N200-A.

All of the allelism tests between the bicolor flower trait and known genes for pattern were performed at Prosser, Wash. In the Fall 2004 and Winter 2005, test crosses were made between line 179c and the genetic tester stocks 5-593 (for $\mathrm{BC}_{3}$ of bicolor to 5-593), $w b \mathrm{BC}_{3} 5-593, v \mathrm{BC}_{3} 5-593$, and $t Z$ Fib $\mathrm{BC}_{3}$ 5-593 (Table 1). Test crosses $w b \mathrm{BC}_{3} 5-593 \times t Z$ Fib $\mathrm{BC}_{3} 5-593$ and $w b \mathrm{BC}_{3} 5-593 \times p^{\text {mic }} \mathrm{BC}_{3} 5-593$ were also made (Table 1). The $\mathrm{F}_{2}$ progenies of the above test crosses with $179 \mathrm{c}$ and the two allelism tests with $w b \mathrm{BC}_{3}$ 5-593 were grown in the field in Summer 2005. Data were recorded on segregation for color and pattern of flowers and seed coats. 

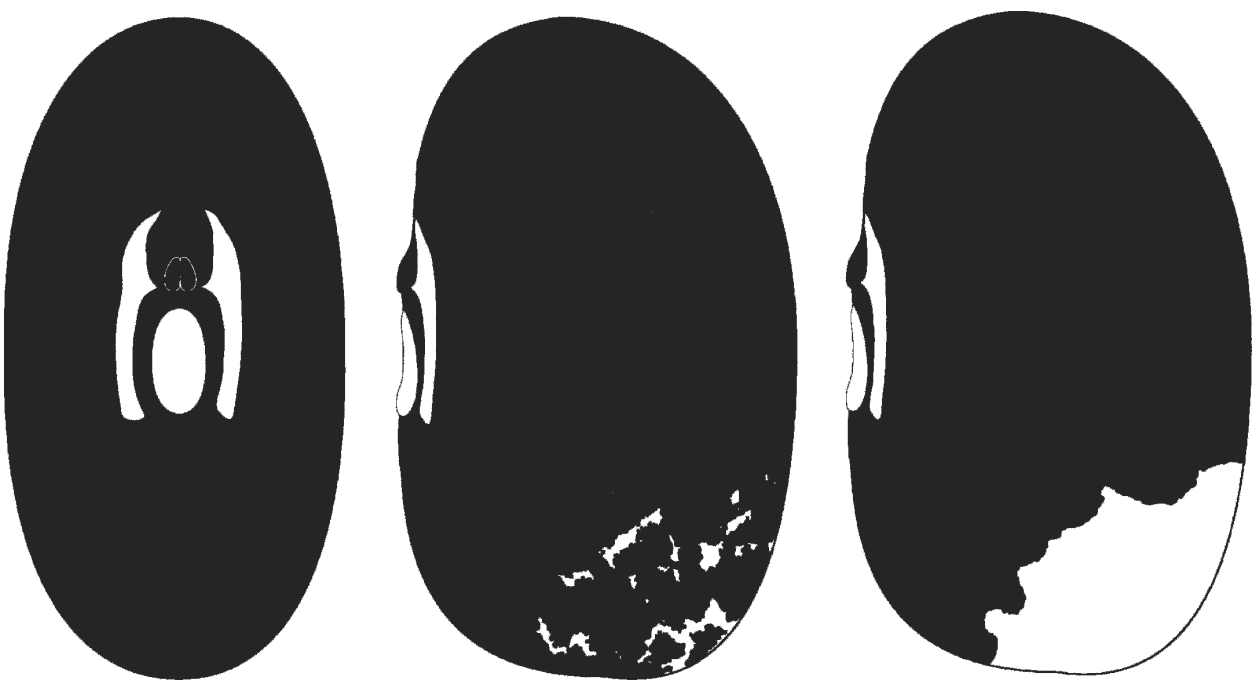

Fig. 2. Ventral view (left seed) and two side views (right seeds) showing the range of variability of the expansa with fibula arcs pattern of partly colored seed coats of common bean expressed by $t$ P Z Bip J Fib.
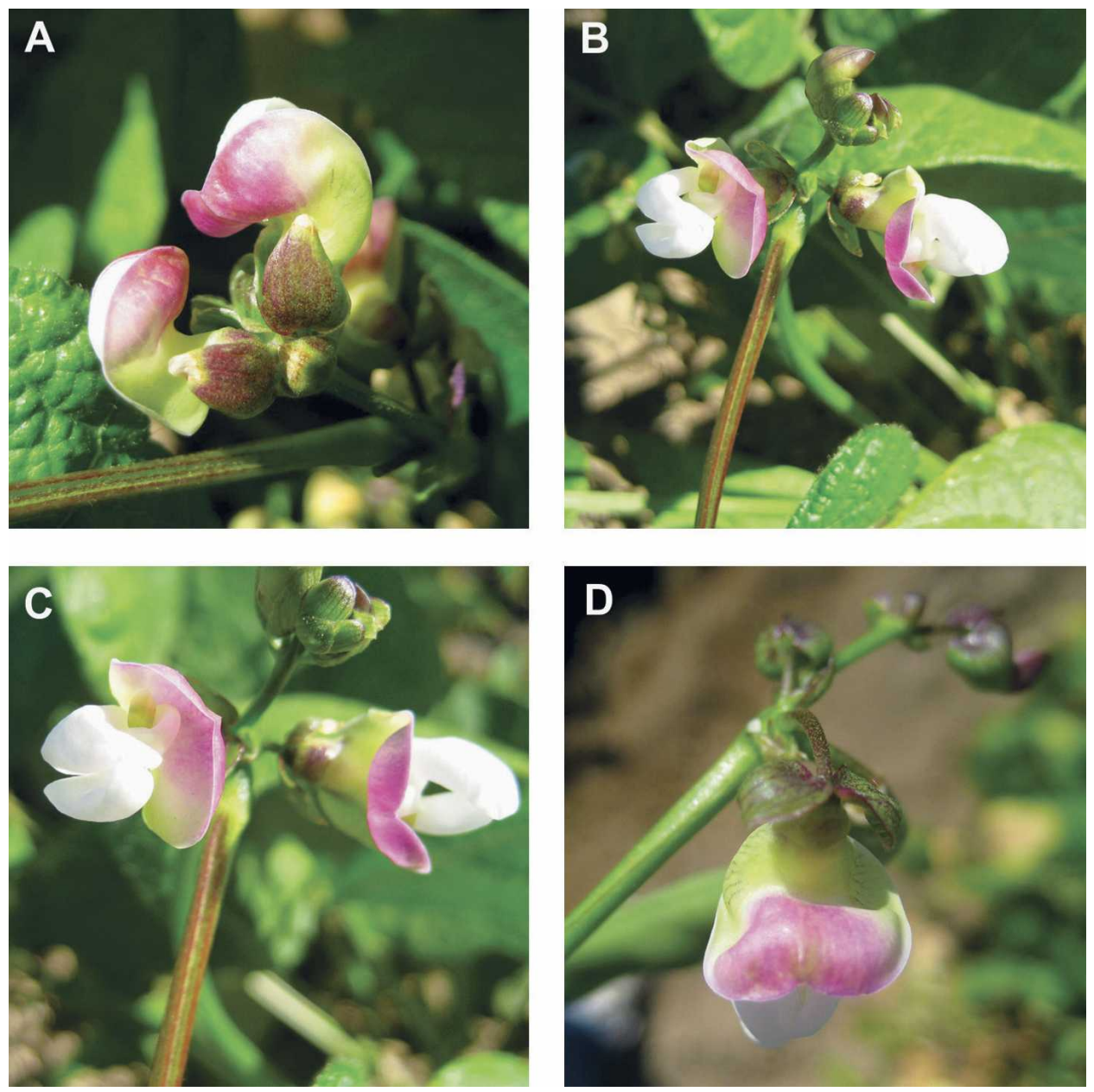

Fig. 3. Flower buds and open flowers of common bean expressing the bicolor (bic) pattern with purple (bishops violet) banner petal and white wing petals: (A) flower buds with sutures splitting open; (B) top view of flowers; (C) anterior view of banner petal (left flower); (D) posterior view of banner petal.

In Fall 2005 and Winter 2006, two additional test crosses were made with $179 \mathrm{c}$, viz., with $V^{\mathrm{wf}} \mathrm{BC}_{3} 5-593$ and $p^{\text {mic }} \mathrm{BC}_{3} 5$ 593. The $F_{2}$ progenies were grown in the field in Summer 2006.
Data were recorded on segregation for color and pattern of flowers and seed coats.

\section{Results and Discussion}

The cross between line $33 \times 5$ 593 segregated for only two classes: 1) plants having black seed coats and purple flowers and 2) plants with "brown" (dark olive brown) seed coats and bicolor flowers (Fig. 3) in a ratio of $3: 1$, respectively (Table 2 ). The data are consistent with the genetic hypothesis that, with $V$, a single, recessive gene (bic) expresses pleiotropic effects: bicolor flowers (bishops violet banner petal and white wing petals) and dark olive brown seed coats. This hypothesis was tested in $\mathrm{F}_{3}$ progenies derived from 35 randomly selected $\mathrm{F}_{2}$ plants from the line $33 \times 5-593$ cross. The $\mathrm{F}_{2}$ parents with black seed coat and purple (bishops violet) flowers either were true breeding for the parental phenotype or segregated in a 3:1 ratio for the two classes observed in $\mathrm{F}_{2}$ (Table 2). All $\mathrm{F}_{2}$ parents with "brown" seed coat and bicolor flowers were true breeding for the parental phenotype (Table 2). The frequency of the three classes of $\mathrm{F}_{3}$ progenies just described fit the expected ratio of 1:2:1, respectively (Table 2). Thus, the hypothesis that a single recessive gene with pleiotropic effects on flower pattern and seed coat color was supported by the $\mathrm{F}_{3}$ progeny tests. We tentatively propose the gene symbol bic for the locus controlling bicolor flower expression, pending allelism tests presented later.

The question remains whether the Bic locus is a new gene locus for the genetics of seed coat and flower pattern or is an allele at some previously reported gene for those traits. Also, further testing is needed for the hypothesis that the flower pattern and seed coat color effects are pleiotropic effects of a single gene and not the effects of two closely linked genes. The third backcross of bic to 5-593 provided additional $F_{2}$ segregation data from a population of 412 plants. No segregation for recombinants between separate genes for bicolor vs. brown seed coat was observed, viz., no plants with 1) bicolor flower and black seed coats or 2) purple flower (no pattern) with 
Table 2. Segregation in common bean for bicolor flower color pattern and seed coat color in the $\mathrm{F}_{2}$ and $\mathrm{F}_{3}$ (from 35 randomly selected $\mathrm{F}_{2}$ parents) from the cross of bicolor flower selection line 33 (bic V) $\times$ purple flower 5-593 (Bic V).

\begin{tabular}{|c|c|c|c|c|c|c|c|}
\hline \multirow[b]{3}{*}{ Generation } & \multirow{3}{*}{$\begin{array}{l}\text { Progenies } \\
\text { (no. })^{z}\end{array}$} & & & \multicolumn{2}{|c|}{ Segregation classes } & \multirow[b]{3}{*}{$\chi^{2}(3: 1)$} & \multirow[b]{3}{*}{$P$} \\
\hline & & \multicolumn{2}{|c|}{ Parental phenotype } & $\begin{array}{l}\text { Black seed, } \\
\text { purple flower }\end{array}$ & $\begin{array}{c}\text { Brown seed, }{ }^{y} \\
\text { bicolor flower }^{x}\end{array}$ & & \\
\hline & & Seed & Flower & $\overline{B i c /-(\text { no. observed) }}$ & $\overline{\text { bic/bic (no. observed) }}$ & & \\
\hline$\overline{F_{2}}$ & 1 & Black & Purple & 55 & 13 & 1.255 & 0.26 \\
\hline $\mathrm{F}_{3}$ & 6 & Black & Purple & 158 & & & \\
\hline $\mathrm{F}_{3}$ & 17 & Black & Purple & 309 & 104 & 0.007 & 0.93 \\
\hline $\mathrm{F}_{3}$ & 12 & Brown $^{y}$ & Bicolor $^{x}$ & & 254 & & \\
\hline
\end{tabular}

${ }^{\mathrm{z} F o r}$ the data 6,17 , and $12, \chi^{2}(1: 2: 1)=2.086, P=0.35$.

y This brown color is darker and more olive than mineral brown, which is expressed by $P C J G B v$, and this seed coat color was never reported previously.

${ }^{x}$ Bicolor flowers have purple (bishops violet) banner petal and white wings (see Fig. 3).

brown seed coats (Table 3). Similarly, neither of the cross-over types was observed in any of the other $F_{2}$ populations derived from crosses with genetic testers involving the $T, P, V$, and $W b$ genes (Table 3). On this basis, the hypothesis of pleiotropy was supported.

The test cross of 179c (bic) with the $\mathrm{P}_{2}$ tester (with $v$ ) showed disturbed segregation with respect to the expected 9:3:4 ratio (Table 3). No reason for this disturbed segregation can be given by the authors. Another $V$ locus tester was used to clarify the linkage question, viz., the test cross of $179 \mathrm{c}$ with $\mathrm{P}_{3}$ (with $V^{\mathrm{wf}}$ ). The $\mathrm{F}_{2}$ segregation showed independent segregation between the Bic and $V$ loci (Table 3). Although segregation at both genes was disturbed, these disturbances were not the result of genetic linkage (Table 3). Thus, the dark olive brown seed coat of $179 \mathrm{c}$ is not due to some new allele at the $V$ locus.

Table 3. A third backcross of the bicolor (tentatively bic) stock $179 \mathrm{c}$ to 5-593, allelism test crosses between the bic flower stock $179 \mathrm{c}$ and five genetic testers, and two additional test crosses between $w b \mathrm{BC}_{3}$ 5-593 and two genetic testers in common bean.

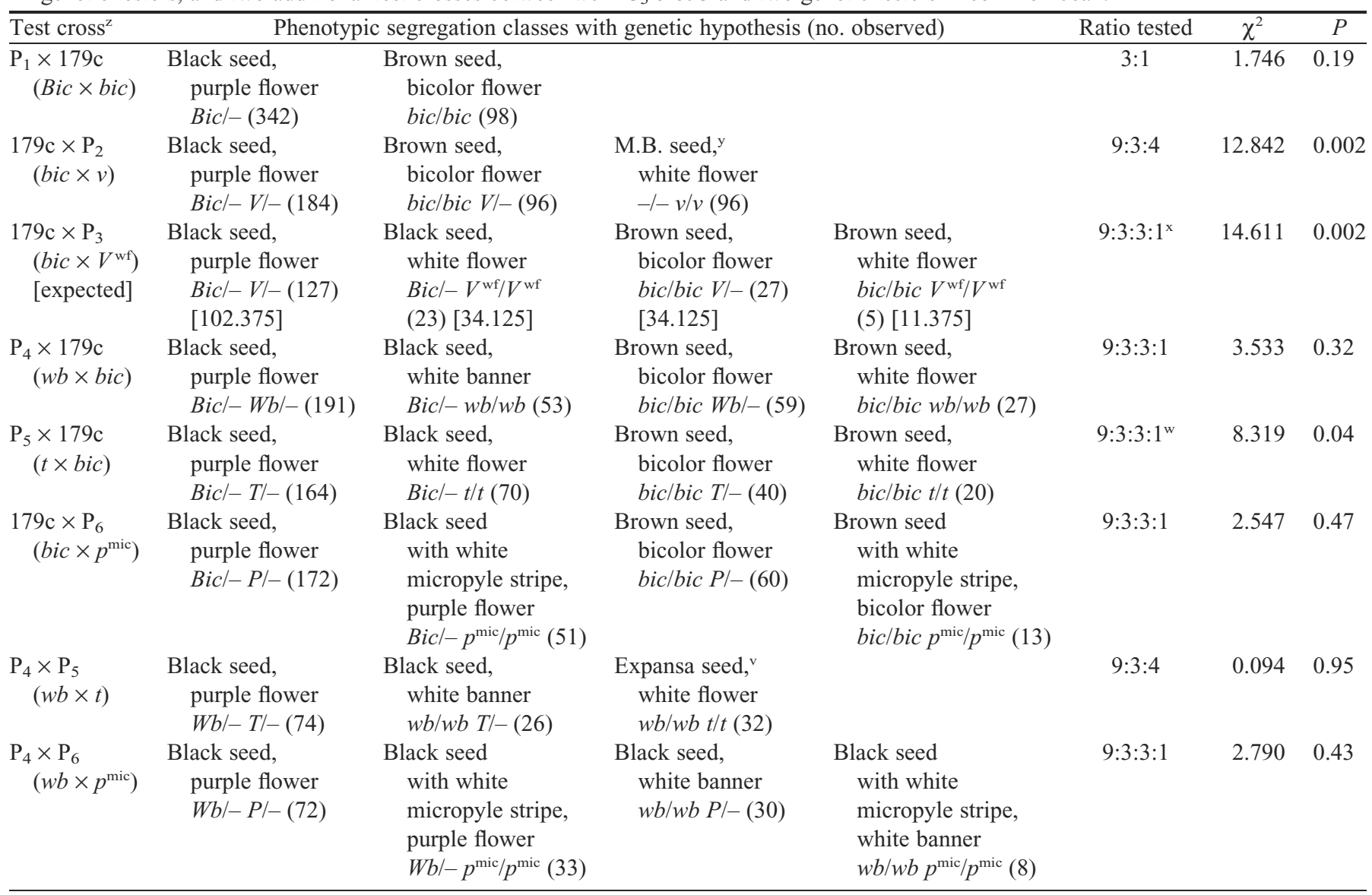

${ }^{\mathrm{z}}$ The genetic tester stocks referenced by $\mathrm{P}$ with subscript numbers are listed in Table 1.

${ }^{\mathrm{y}}$ M.B. = mineral brown seed coat color with genotype $T P C J G B v$.

${ }^{\mathrm{x}}$ For the test cross $\mathrm{P}_{3} \times 179 \mathrm{c}$, the orthogonal contrasts are as follows: $\chi^{2}{ }_{B i c}=5.341, P=0.021, \chi^{2}{ }_{V}=8.974, P=0.005 ; \chi^{2}{ }_{L}=0.296, P=0.59$.

${ }^{w}$ For the test cross $P_{5} \times 179 \mathrm{c}$, the orthogonal contrasts are: $\chi^{2}{ }_{T}=4.939, P=0.03 ; \chi^{2}{ }_{B i c}=3.306, P=0.07 ; \chi^{2}{ }_{L}=0.074, P=0.79$.

${ }^{\vee}$ Expansa $=$ expansa with fibula arcs (Fig. 2). 
The flower color pattern gene $w b\left(\mathrm{P}_{4}\right)$ was crossed with $179 \mathrm{c}$ (bic) to test the hypothesis that a new allele at $\mathrm{Wb}$ may control the bicolor pattern. The $\mathrm{F}_{2}$ progeny showed independent segregation at the Bic and $\mathrm{Wb}$ loci (Table 3). Thus, our original preliminary hypothesis was demonstrated to be false. Similarly, the $t$ gene $\left(\mathrm{P}_{5}\right)$ for partly colored seed coats was crossed with 179c (bic) to test the hypothesis that a new allele at $T$ may control the bicolor pattern. The $\mathrm{F}_{2}$ segregation was disturbed at $T$, but the orthogonal contrasts showed that the disturbance was not due to genetic linkage (Table 3). The allelism test of Bic with $P\left(\mathrm{P}_{6}\right)$ also showed independent segregation at those loci (Table 3). Two other allelism test crosses were made to complete the set of allelism tests needed to more completely establish the independence of $w b$ from two other genes affecting flower color expression, viz., $t$ and $p^{\text {mic }}$. In both cases, there was independent segregation between the $W b$ locus and the other two loci (Table 3). Thus, the genes $T, P, V, W b$, and $B i c$ are conclusively demonstrated to be independent loci. On the basis of all the above results, we formally propose that the gene symbol bic be given to the gene for bicolor flower (Fig. 3), originally derived from the $P$. coccineus source 'Painted Lady'.

\section{Literature Cited}

Bassett, M.J. 1993. A new gene for flower color pattern, white banner $(w b)$, in progeny of an interspecific hybrid between common bean and scarlet runner beans. J. Amer. Soc. Hort. Sci. 118:878-880.
Bassett, M.J. 1994a. The genotype for seed coat color of breeding line 5-593. Annu. Rpt. Bean Improv. Coop. 37:244-245.

Bassett, M.J. 1994b. The griseoalbus (gray-white) seed coat color is controlled by an allele $\left(p^{\text {gri }}\right)$ at the $P$ locus in common bean. HortScience 29:1178-1179.

Bassett, M.J. 1996. New genes, stp and $s t p^{\text {hbw }}$, for flower and seed coat pattern in common bean. J. Amer. Soc. Hort. Sci. 121:388-392.

Bassett, M.J. 1997. A new allele $\left(V^{\mathrm{wf}}\right)$ at the $V$ locus for flower and seed coat color in common bean. J. Amer. Soc. Hort. Sci. 122:519-521.

Bassett, M.J. 1998. A third recessive allele, $s t p^{\text {mic }}$, for seed coat pattern at the Stp locus in common bean. J. Amer. Soc. Hort. Sci. 123:404-406.

Bassett, M.J. 2003a. Allelism between the $P$ and Stp genes for seed coat color and pattern in common bean. J. Amer. Soc. Hort. Sci. 128:548-551.

Bassett, M.J. 2003b. Inheritance of scarlet color and vein pattern in flowers and oxblood red seed coat color derived from the interspecific cross of common bean with scarlet runner bean (Phaseolus coccineus L.). J. Amer. Soc. Hort. Sci. 128:559-563.

Bassett, M.J. 2007. Genetics of seed coat color and pattern in common bean. Plant Breed. Rev. 28:239-315.

Bassett, M.J., C. Shearon, and P. McClean. 1999. Allelism found between two common bean genes, hilum ring color $(D)$ and partly colored seed coat pattern $(Z)$, formerly assumed to be independent. J. Amer. Soc. Hort. Sci. 124:649-653.

Lamprecht, H. 1941. Die Artgrenze zwischen Phaseolus vulgaris L. und multiflorus Lam. Hereditas 27:51-175.

Lamprecht, H. 1948. On the effect and linkage of genes transmitted from Phaseolus coccineus to Ph. vulgaris. Agr. Hort. Genet. 6:64-81. 